DOI: https://doi.org/10.32689/2523-4536/60-8

УДК 657.11:336.226

Мокіснко Т. В.

кандидат економічних наук, доцент, доцент кафедри бухгалтерського обліку та економічного контролю,

Полтавська державна аграрна академія

ORCID: https://orcid.org/0000-0003-1344-4981

Прийдак Т. Б.

кандидат економічних наук, доцент кафедри бухгалтерського обліку та економічного контролю,

Полтавська державна аграрна академія

ORCID: https://orcid.org/0000-0002-9257-0419

Красота О. $\Gamma$.

кандидат економічних наук, доцент, доцент кафедри бухгалтерського обліку та економічного контролю,

Полтавська державна аграрна академія

ORCID: https://orcid.org/0000-0003-3082-1363

Mokiienko Tetiana

Candidate of Economics, Assistant Professor, Associate Professor of Accounting Department, Poltava State Agrarian Academy

Priydak Tetiana

Candidate of Economics, Associate Professor of Accounting Department, Poltava State Agrarian Academy

Krasota Olena

Candidate of Economics, Associate Professor of Accounting Department, Poltava State Agrarian Academy

\title{
УТРИМАННЯ ІЗ ЗАРОБІТНОЇ ПЛАТИ: ВІД ДЕВ'ЯНОСТИХ ДО СЬОГОДНІ
}

\section{DEDUCTIONS FROM WAGES: FROM THE NINETIES TO TODAY}

\footnotetext{
У статті досліджено історичні аспекти утримань із заробітної плати працівників та їх облікове відображення, так як порядок утримань із заробітної плати працівників - тема не нова, проте завжди актуальна. За результатами проведеного дослідження встановлено, шчо види утримань із заробітної плати за часи незалежності Украӥни зазнали суттєвих змін. Досить часто операчії з утримання коштів викликають суперечності між працівниками і роботодавиями.
}

The implementation of social security programmes in developing countries is an important and challenging task, given the fact that capital and insurance markets are largely underdeveloped and budgetary constraints are high. In the context of the transformation of social and economic processes in society, the appropriate level of insurance development provides not only monetary payments in the case of occurrence of insured events, but also creates legal and economic conditions for stimulating effective work. The basis of the system of social protection of the population should be state social insurance, carried out on a mandatory basis. After all, no state, even a highly developed one, build a social insurance system that is able to fully and effectively meet the needs of all segments of the population. The challenges facing our state in modern conditions lead to significant economic and social losses. Mitigation and limitation of the negative impact of such instability on citizens is possible in the case of creation an effective system of social protection, able to provide social support and implementation of social functions. Mandatory accruals and deductions from the salary of the unified social contribution are in the focus of various users of accounting information. They determine the amount of wages to be paid for employees and form an effective system of social protection for the population. They act as a component of expenses that determine the cost of products and affect the financial result of economic activity for the business entity. They play an important role for the state in generating revenues to ensure the performance of social functions. The value of mandatory accruals and deductions is assessed differently for each of the parties, but their implementation concerns the interests of all users. Such costs are regulated by law. The law regulates the payment of such wage deductions as a unified social contribution, which replaced the fees to the Pension Fund and other social insurance funds. All these events make the necessary of the further research of the state and problems of the obligatory state social insurance in Ukraine in modern realities. 
Утримання із заробітної плати працівника - це неперерахування (невидача) частини його заробітної плати та виплат, що прирівнюються до неї, які належать працівнику, в забезпечення вимог до цього працівника або з боку роботодавця, або з боку третіх осіб, що здійснюється у випадках, розмірах та порядку, встановлених нормами чинного законодавства України.

Становлення системи оподаткування доходів фізичних осіб в Україні, яка мала певні відмінності від практики прибуткового оподаткування за радянських часів, почалося в 1991 році. Після розпаду СРСР були встановлені умови та ставки оподаткування прибуткового податку для всіх категорій платників. Особливим фактором розвитку системи прибуткового оподаткування в Україні в 1991-1992 роках стала постійна зміна інтервалів і ставок прогресивного оподаткування в залежності від розміру доходу.

Ще в Українській РСР 1991 року було прийнято Закон «Про прибутковий податок з громадян Української РСР, іноземних громадян та осіб без громадянства» за яким мінімальна заробітна плата, що не обкладалася податком, була встановлена в розмірі 185 рублів і склала неоподатковуваний мінімум. Але вже з 26 грудня 1992 року оподаткування доходів громадян здійснювалося відповідно до Декрету Кабінету Міністрів України «Про прибутковий податок з громадян», який зі змінами і доповненнями діяв до травня 2003 року.

А після набрання чинності Закон України «Про податок 3 доходів фізичних осіб» 1 січня 2004 року (до нього додатково видані Інструкція «Про оподаткування фізичних осіб-підприємців» і Інструкція «Про податковий кредит 3 податку з доходів фізичних осіб») [3; 4].

Фонд оплати праці суб'єктів господарювання виступає базою для нарахування внесків до ряд соціальних фондів. Таких як: Пенсійний фонд України, Фонд ліквідації наслідків Чорнобильської катастрофи (збір в цей фонд встановлений законодавством як відсоток від фонду оплати праці та стягувався до 1999 року включно), Фонд соціального страхування (з 2001 року - Фонд соціального страхування 3 тимчасової втрати працездатності), Фонд сприяння зайнятості населення (з 2001 року - Фонд соціального страхування на випадок безробіття), Фонд соціального страхування від нещасних випадків на виробництві та професійних захворювань України (далі - Фонд соціального страхування від нещасних випадків на виробництві).

По кожному $з$ перерахованих фондів встановлена відповідна ставка внесків. Вказані внески (утримання) характеризують загальне навантаження на фонд оплати праці (далі ФОП). У табл. 1 представлена динаміка ставок внесків до Пенсійного фонду, Фонду соціального страхування і загальне навантаження на ФОП за період 1992-2000 років.

Як бачимо, найвищий рівень навантаження на ФОП спостерігався протягом 16-місячного періоду (з 1 березня 1992 рік до 1 травня 1993 рік). Перше істотне зменшення навантаження пов'язане зі зниженням ставки у 1,65 разів (з 61 до 37\%) (з 2 липня 1993 року) ставки нарахувань на соціальне страхування (остання розділилася на дві складові - до Пенсійного фонду України та Фонду соціального страхування).

Наступне зменшення ставки обумовлено поетапним зниженням ставки збору до Фонду ліквідації наслідків Чорнобильської катастрофи: спочатку вона встановлена на рівні $12 \%$, яка «трималася» більше п'яти років (з березня 1992 року по липень 1997 року). Ставка цього збору, врешті-решт, була зменшена спочатку до 10\% (діяла близько року), потім до розміру 5\% (на наступні півроку), а 3 кінця січня 1999 року утримання до Фонду, було взагалі припинено. Як наслідок, протягом 1999-2000 років, рівень навантаження на ФОП фактично був найнижчим за всю історію незалежної України - 37,5\% [7].

Ставки внесків до Пенсійного фонду (ПФ) і Фонд соціального страхування (ФСС) Таблиця 1 за 1992-2000 роки, \%

\begin{tabular}{|c|c|c|c|c|}
\hline Період & $\begin{array}{c}\text { Загальне } \\
\text { навантаження } \\
\text { на фонд } \\
\text { оплати праці } \\
\end{array}$ & Фонд & $\begin{array}{c}\text { Для підприємств, установ } \\
\text { та організацій, які } \\
\text { використовують працю } \\
\text { найманих працівників }\end{array}$ & $\begin{array}{c}\text { Для підприсмств, установ } \\
\text { та організацій, які } \\
\text { використовують працю } \\
\text { людей з інвалідністю } \\
\end{array}$ \\
\hline \multirow{2}{*}{$\begin{array}{l}3 \text { 01.01.1992 } \\
\text { по 01.05.1993 рр. }\end{array}$} & \multirow{2}{*}{61} & ПФ & 55,88 & 31,82 \\
\hline & & $\Phi C C$ & 8,4 & 5,18 \\
\hline \multirow{2}{*}{$\begin{array}{l}3 \text { 01.05.1993 } \\
\text { по 07.02.1996 pр. }\end{array}$} & \multirow{2}{*}{37} & ПФ & 32,56 & 4,4 \\
\hline & & $\Phi C C$ & 4,4 & 0,6 \\
\hline \multirow{2}{*}{$\begin{array}{l}\text { з 07.02.1996 } \\
\text { по 31.12.2000 pр. }\end{array}$} & \multirow{2}{*}{37} & $\Pi \Phi$ & 32 & 4 \\
\hline & & $\Phi C C$ & 5 & 0,6 \\
\hline
\end{tabular}


Наступний етап зростання навантаження на ФОП пов'язаний зі створенням у 2001 році Фонду соціального страхування від нещасних випадків на виробництві. Залежно від класу професійного ризику виробництва діяльності економічного суб'єкта, обов'язковий розмір внесків був визначений в розмірі від $0,2 \%$ (найнижчий рівень ризику) до 13,6\% (найвищий рівень ризику). 3 урахуванням періодичних змін базового розміру внесків до всіх соціальних фондів рівень навантаження на ФОП в наступні десять років (2001-2010 роки) перебував в діапазоні 34,8-37,2\% для суб'єктів, які здійснювали внески до Фонду за найнижчою ставкою і 48,4-50,8\% - за високою.

Динаміка ставок нарахувань і утримань до Фондів за 2002-2011 року представлено в табл. 2.

Податковий кодекс України став вершиною еволюції податкового законодавства. 32011 року був прописаний механізм стягнення переважної більшості податків і зборів, в тому числі і податку на доходи фізичних осіб [3].

3 липня 2011 року набрав чинності Закон України «Про збір та облік єдиного внеску на загальнообов'язкове державне соціальне страхування». Єдиний внесок на загально- обов'язкове державне соціальне страхування (далі - ССВ) являє собою консолідований страховий внесок, збір якого здійснюється до системи загальнообов'язкового державного соціального страхування, в обов'язковому порядку і на регулярній основі, 3 метою захистити застрахованих осіб і членів їх сімей, у випадках, передбачених законодавством, на отримання страхових виплат (послуг) за діючими видами загальнообов'язкового державного соціального страхування [5].

У 2011 році він замінив собою 4 окремих утримання, які існували до цього. А саме: до Пенсійного фонду, до фондів страхування на випадок безробіття, у фонд з тимчасової втрати працездатності, в фонд від нещасних випадків на виробництві.

На початковому етапі впровадження $\mathrm{CCB}$, його розмір залежав від класу професійного ризику виробництва (67 класів). Ставка ССВ становила: від 36,76\% для першого класу від $49,7 \%$ для 67 класу.

32016 року, ССВ не утримується із заробітної плати працівника. Нарахування ССВ здійснює роботодавець на ФОП. Ставка ССВ становить 22\%, крім господарюючих суб'єктів, які використовують найману працю, людей 3 обмеженими можливостями $(5,3,5,5$ та $8,41 \%)$.

Таблиця 2

Розміри страхових тарифів за видами державного соціального страхування за 2002-2011 року

\begin{tabular}{|c|c|c|c|c|c|}
\hline \multirow[b]{2}{*}{ Період } & \multicolumn{2}{|l|}{ ФСС ВПТ } & \multicolumn{2}{|c|}{ ФСС НСБ } & \multirow{2}{*}{$\begin{array}{c}\text { ФСС НСП } \\
\begin{array}{c}\text { нарахування } \\
\text { на роботодавця }\end{array}\end{array}$} \\
\hline & $\begin{array}{c}\text { утримання із доходів } \\
\text { працівників }\end{array}$ & $\begin{array}{c}\text { нарахування } \\
\text { на робото- } \\
\text { Давця }\end{array}$ & $\begin{array}{c}\text { утримання } \\
\text { із доходів } \\
\text { працівників }\end{array}$ & $\begin{array}{c}\text { нарахування } \\
\text { на робото- } \\
\text { давця }\end{array}$ & \\
\hline 2002 p. & $\begin{array}{c}0,25 \% \text { - при ЗП <150 грн. } \\
0,5 \% \text { - при ЗП до >150 грн. }\end{array}$ & $2,9 \%$ & $0,5 \%$ & $2,1 \%$ & $2,32 \%$ \\
\hline $2003 \mathrm{p}$. & $\begin{array}{c}0,25 \% \text { - при ЗП <150 грн. } \\
0,5 \% \text { - при ЗП до > } 150 \text { грн. }\end{array}$ & $2,9 \%$ & $0,5 \%$ & $2,1 \%$ & $2,32 \%$ \\
\hline 2004 p. & $\begin{array}{l}0,5 \%-3 / \Pi<\Pi M \\
1,0 \%-3 / \Pi>\Pi M\end{array}$ & $2,9 \%$ & $0,5 \%$ & $1,9 \%$ & $2,32 \%$ \\
\hline 2005 p. & $\begin{array}{l}0,5 \%-3 / \Pi<\Pi M \\
1,0 \%-3 / \Pi>\Pi M\end{array}$ & $2,9 \%$ & $0,5 \%$ & $1,9 \%{ }^{1}, 1,6 \%{ }^{2}$ & $2,32 \%$ \\
\hline 2006 p. & $\begin{array}{l}0,5 \%-3 / \Pi<\Pi M \\
1,0 \%-3 / \Pi>\Pi M\end{array}$ & $2,9 \%$ & $0,5 \%$ & $1,3 \%$ & $2,32 \%$ \\
\hline 2007 p. & $\begin{array}{l}0,5 \%-3 / \Pi<\Pi M \\
1,0 \%-3 / \Pi>\Pi M\end{array}$ & $1,5 \%$ & $0,5 \%$ & $1,3 \%$ & $2,32 \%$ \\
\hline 2008 p. & $\begin{array}{l}0,5 \%-3 / \Pi<\Pi M \\
1,0 \%-3 / \Pi>\Pi M\end{array}$ & $1,5 \%$ & $0,5 \%$ & $1,3 \%$ & $2,32 \%$ \\
\hline 2009 p. & $\begin{array}{l}0,5 \%-3 / \Pi<\Pi M \\
1,0 \%-3 / \Pi>\Pi M\end{array}$ & $1,4 \%$ & $0,6 \%$ & $1,6 \%$ & $2,42 \%$ \\
\hline 2010 p. & $\begin{array}{l}0,5 \%-3 / \Pi<\Pi M \\
1,0 \%-3 / \Pi>\Pi M\end{array}$ & $1,4 \%$ & $0,6 \%$ & $1,6 \%$ & $2,42 \%$ \\
\hline 2011 p. & $27,7778 \%$ від ЕCВ ${ }^{1}$ & $\begin{array}{l}3,7645 \% \text { oT } \\
\mathrm{ECB}^{2}\end{array}$ & $\begin{array}{c}16,6667 \% \text { от } \\
\text { ЕCB }\end{array}$ & $\begin{array}{c}4,0333 \% \\
\text { от ECB }\end{array}$ & $\begin{array}{l}2,9309 \% \\
\text { oт ECB }\end{array}$ \\
\hline
\end{tabular}

${ }^{1}$ Сдиний внесок на загальнообов'язкове державне соціальне страхування для найманих працівників утримується за ставкою 3,6\%;

${ }^{2}$ Сдиний внесок на загальнообов'язкове державне соціальне страхування для підприємств, що відносяться до 22 класу професійного ризику справляється за ставкою 37,19\% (залежно від класу професійного ризику виробництва, в якій працює господарюючий суб'єкт). 
На даний час існує обмеження по розміру суми мінімального та максимального ССВ, що може бути нарахована. Їх розміри залежать від мінімальної заробітної плати, станом на 01 січня поточного року (на 01.01.2020 року мінімальна з/п дорівнює 4723 грн.). Мінімальна сума $\mathrm{CCB}$ (розрахунок проводиться виходячи 3 суми мінімальної заробітної плати) становить 1039,06 грн., а його максимальний розмір (15 мінімальних заробітних плат) - 15585,90 грн.

Облік єдиного соціального внеску ведеться на субрахунку 651 «За розрахунками із загальнообов'язкового державного соціального страхування». Нарахування ССВ відображається по кредиту 651 рахунку. Під час нарахування єдиного соціального внеску складається така кореспонденція рахунків: Дт 23, 91, 92, 93, 94 Кт 651. Сплата ССВ відображається по дебету 651 рахунку (Дт 651 Кт 311).

Податок на доходи фізичних осіб (ПДФО) податок, який утримується із заробітної плати працівників і виплат, які можна до них прирівняти. Перелік доходів, які оподатковуватимуться, як і ставка самого податку, змінювалися протягом усього періоду дослідження і регулювалися відповідними нормативними актами. Відсоткова ставка ПДФО в Україні в

Ставки ПДФО і розміри податкової соціальної пільги за 1992-2020 року

Таблиця 3

\begin{tabular}{|c|c|c|c|c|c|c|c|}
\hline$\underset{\text { (рік) }}{\text { Період }}$ & $\begin{array}{c}\text { Базова ставка } \\
\text { ПНГ (НДФЛ), } \\
\%\end{array}$ & $\begin{array}{c}\text { Розмір } \\
\text { податкової } \\
\text { соціальної } \\
\text { пільги }\end{array}$ & \multicolumn{3}{|c|}{$\begin{array}{c}\text { Сума податкової } \\
\text { соціальної пільги, } \\
\text { на 01.01, руб. до } \\
1997 \text { р., грн. } 31997 \text { р. }\end{array}$} & $\begin{array}{c}\text { Прожитковий } \\
\text { мінімум на 01.01, } \\
\text { руб. до } 1997 \text { р., } \\
\text { грн. } 31997 \text { р. }\end{array}$ & $\begin{array}{c}\text { Мінімальна } \\
\text { заробітна } \\
\text { плата на 01.01, } \\
\text { руб. до } 1997 \text { p., } \\
\text { грн. } 31997 \text { р. }\end{array}$ \\
\hline 1992 & \multirow{12}{*}{$\begin{array}{c}\text { Прогре- } \\
\text { сивна ставка } \\
\text { оподаткування. } \\
\text { Розмір від } \\
10 \text { до } 40 \%\end{array}$} & \multirow{12}{*}{$\begin{array}{l}\text { до } 5 \text { МЗП } \\
(\mathrm{HM}) \\
\text { до } 10 \mathrm{M} 3 \Pi \\
(\mathrm{HM})\end{array}$} & \multirow{2}{*}{$\begin{array}{c}\text { до } 925 \\
\text { до } 2000\end{array}$} & \multicolumn{2}{|c|}{ до 1850} & \multirow{7}{*}{$\begin{array}{c}\text { поняття } \\
\text { «прожитковий } \\
\text { мінімум» не } \\
\text { застосовувався. } \\
\text { Застосовувався } \\
\text { термін «мінімальної } \\
\text { місячної } \\
\text { заробітної плати } \\
\text { (неоподатковуваний } \\
\text { мінімум)» }\end{array}$} & 185 \\
\hline 1993 & & & & \multicolumn{2}{|c|}{ до 4000} & & 400 \\
\hline 1994 & & & до 300000 & \multicolumn{2}{|c|}{ до 600000} & & 60000 \\
\hline 1995 & & & до 300000 & \multicolumn{2}{|c|}{ до 600000} & & 60000 \\
\hline 1996 & & & до 300000 & \multicolumn{2}{|c|}{ до 600000} & & 60000 \\
\hline 1997 & & & до 75 & \multicolumn{2}{|c|}{ до 150} & & 15 \\
\hline 1998 & & & до 225 & \multicolumn{2}{|c|}{ до 450} & & 45 \\
\hline 1999 & & & до 370 & \multicolumn{2}{|c|}{ до 740} & & 74 \\
\hline 2000 & & & до 450 & \multicolumn{2}{|c|}{ до 900} & 271 & 90 \\
\hline 2001 & & & до 590 & \multicolumn{2}{|c|}{ до 1180} & 311 & 118 \\
\hline 2002 & & & до 700 & \multicolumn{2}{|c|}{ до 1400} & 342 & 140 \\
\hline 2003 & & & до 925 & \multicolumn{2}{|c|}{ до 1850} & 342 & 185 \\
\hline 2004 & 13 & \multirow{13}{*}{$\begin{array}{c}100 \%, \\
150 \%, 200 \% \\
\text { (із розрахунку } \\
50 \% \text { від } \\
\text { мінімальної } \\
\text { заробітної } \\
\text { плати) }\end{array}$} & 102,5 & 153,75 & 205 & 362 & 205 \\
\hline 2005 & 13 & & 131 & 196,5 & 262 & 423 & 262 \\
\hline 2006 & 13 & & 175 & 262,5 & 350 & 453 & 350 \\
\hline 2007 & 15 & & 200 & 300 & 400 & 492 & 400 \\
\hline 2008 & 15 & & 257,5 & 386,25 & 515 & 592 & 515 \\
\hline 2009 & 15 & & 302,5 & 453,75 & 605 & 626 & 605 \\
\hline 2010 & 15 & & 434,5 & 651,75 & 869 & 825 & 869 \\
\hline 2011 & 15 & & 470,5 & 705,75 & 941 & 894 & 941 \\
\hline 2012 & $15(17)$ & & 536,5 & 804,75 & 1073 & 1017 & 1073 \\
\hline 2013 & $15(17)$ & & 573,5 & 860,25 & 1147 & 1108 & 1147 \\
\hline 2014 & $15(17)$ & & 609 & 913,5 & 1218 & 1176 & 1218 \\
\hline 2015 & $15(20)$ & & 609 & 913,5 & 1218 & 1176 & 1218 \\
\hline 2016 & 18 & & 689 & 1033,5 & 1378 & 1330 & 1378 \\
\hline 2017 & 18 & \multirow{4}{*}{$\begin{array}{c}100 \%, \\
150 \%, 200 \% \\
\text { (iз розрахунку } \\
50 \% \text { від } \\
\text { прожиткового } \\
\text { мінімуму) }\end{array}$} & 800 & 1200 & 1600 & 1600 & 3200 \\
\hline 2018 & 18 & & 836 & 1254 & 1672 & 1672 & 3723 \\
\hline 2019 & 18 & & 960,5 & 1440,8 & 1921 & 1921 & 4173 \\
\hline 2020 & 18 & & 1051 & 1576,5 & 2102 & 2102 & 4723 \\
\hline
\end{tabular}


2020 році складає 18\%. Облік розрахунків за податком 3 доходів фізичних осіб ведеться на рахунку 64 «Розрахунки за податками та платежами», 641 субрахунок «Розрахунки за податками». При утриманні ПДФО складається кореспонденція рахунків: Дт 661 Кт 641. Перерахування ПДФО до бюджету відображається в обліку наступним чином: Дт 641 Кт. 611.

При оподаткуванні доходів фізичних осіб, можливе зменшення бази оподаткування на суму податкової соціальної пільги (ПСП), за умови та наявності певних умов.

Розмір податкової соціальної пільги (ПСП) в період з 1992 року по 2002 рік для різних категорій громадян становить: до 5 мінімальних заробітних плат (неоподатковуваний мінімум), до 10 мінімальних заробітних плат (неоподатковуваний мінімум). 32003 до 2016 рік соціальна податкова пільга становить 50\% від мінімальної заробітної плати, що визначена станом на перше січня поточного року. А з 2016 року ПСП дорівнює 50\% прожиткового мінімуму громадян, встановленого на 01.01 поточного року.

Граничний розмір доходу, при якому можливе застосування соціальної пільги, дорівнює розміру місячного прожиткового мінімуму, діючого для працездатної особи на 1 січня звітного податкового року, помноженого на коефіцієнт 1,4 та округленого до найближчих 10 гривень. Ставки ПДФО і ПСП за 1992-2020 року згруповані і представлені в табл. 3.

Загалом, податок на доходи фізичних осіб як в СРСР, так і в незалежній Україні був і $є$ загальнодержавним податком, суть якого в рамках децентралізації влади істотно змінилася.

Таким чином, історія справляння податку на доходи фізичних осіб свідчить про: його обов'язковість (з метою фінансування державних витрат); широкому спектрі пільг по оподаткуванню; застосування прогресивних ставок податку залежно від виду і розміру доходів.
Крім того, з січня 2015 року, з доходів фізичних осіб утримується військовий збір. Військовий збір в Україні ввели як тимчасовий податок. Відповідно до Податкового Кодексу України, військовий збір діє до закінчення реформування Збройних сил України [2]. На субрахунку 642 «Розрахунки за обов'язковими платежами» ведеться облік утримань військового збору. Утримання та сплата військового збору оформлюється записами: Дт 661 Кт 642, Дт 642 Кт 311.

Базою оподаткування військовим збором $\epsilon$ (по резидентам): загальний місячний (річний) оподатковуваний дохід; доходи 3 джерелом походження в Україні, які обкладаються ПДФО при їх нарахуванні, виплати, нарахування; іноземні доходи. Для нерезидентів об'єктом військового збору є такі ж доходи, крім іноземних доходів.

Ставка військового збору в Україні становить 1,5\% від бази оподаткування. Хоча, відповідно проекту Закону № 2252-1, розглядається можливість впровадження прогресивної ставки внеску в залежності від рівня доходу: від $0,5 \%$ до $6,5 \%$ [6].

Таким чином, провівши дослідження можна зробити висновки, що за період незалежності України, з доходів громадян утримувалися такі податки і збори: прибутковий податок (податок на доходи фізичних осіб); утримання до Пенсійного фонду, фонду соціального страхування з тимчасової втрати працездатності, фонду соціального страхування на випадок безробіття; єдиний соціальний внесок; військовий збір. Крім того, на фонд оплати праці проводились нарахування: до Пенсійного фонду, Фонду ліквідації наслідків Чорнобильської катастрофи, до фондів соціального страхування (на випадок безробіття, втрати працездатності, нещасних випадків на виробництві), Єдиний соціальний внесок.

Список використаних джерел:

1. Безкровний О.В., Дорошенко О.О. Становлення та розвиток прибуткового оподаткування фізичних осіб. Наукові прачі Полтавської державної аграрної академії. Серія: Економічні науки. 2015. Випуск 1 (10). С. 91-96.

2. Податковий кодекс України № 2755-VI від 02.12.2010 p. Верховна Рада України. URL: https://zakon.rada.gov.ua/laws/show/2755-17/ed20101202.

3. Про податок з доходів фізичних осіб : Закон України № 889-IV від 22.05.2003 р. Верховна Рада України. URL: https://zakon.rada.gov.ua/ laws/show/889-15.

4. Про прибутковий податок з громадян : Декрет Кабінету Міністрів України. № 13-92 від 26.12.1992 p. Кабінет Міністрів України. URL: https://zakon.rada.gov.ua/laws/show/13-92.

5. Про збір та облік єдиного внеску на загальнообов'язкове державне соціальне страхування : Закон України № 2464-VI від 08.07.2010 р. Верховна Рада України. URL: https://zakon.rada.gov.ua/laws/ show/2464-17.

6. Про внесення змін до Податкового кодексу України відносно диференціації ставки військового збору : проект Закону України № 2252-1 від 25.10.2019 р. Верховна Рада України. URL: http://w1.c1.rada.gov.ua/pls/zweb2/webproc4_1?pf3511=67183. 
7. Юшко С.В. Навантаження на фонд оплати праці суб'єктів господарювання як фактор тінізації доходів громадян. Фінанси України. 2013. № 2. С. 32-36.

\section{References:}

1. Bezkrovnyi O.V., Doroshenko O.O. (2015) Stanovlennia ta rozvytok prybutkovoho opodatkuvannia fizychnykh osib. Naukovi pratsi Poltavskoi derzhavnoi ahrarnoi akademii. Seriia: Ekonomichni nauky. Vypusk 1 (10), pp. 91-96.

2. Podatkovyi kodeks Ukrainy № 2755-VI vid 02.12.2010 r. Verkhovna Rada Ukrainy. Available at: https://zakon.rada.gov.ua/laws/show/2755-17/ed20101202.

3. 6. Pro podatok z dokhodiv fizychnykh osib: Zakon Ukrainy № 889-IV vid 22.05.2003 r. Verkhovna Rada Ukrainy. Available at: https://zakon.rada.gov.ua/ laws/show/889-15.

4. Pro prybutkovyi podatok z hromadian: Dekret Kabinetu Ministriv Ukrainy. № 13-92 vid 26.12.1992 r. Kabinet Ministriv Ukrainy. Available at: https://zakon.rada.gov.ua/laws/show/13-92.

5. Pro zbir ta oblik yedynoho vnesku na zahalnooboviazkove derzhavne sotsialne strakhuvannia: Zakon Ukrainy № 2464-VI vid 08.07.2010 r. Verkhovna Rada Ukrainy. Available at: https://zakon.rada.gov.ua/laws/ show/2464-17.

6. Pro vnesennia zmin do Podatkovoho kodeksu Ukrainy vidnosno dyferentsiatsii stavky viiskovoho zboru: proekt Zakonu Ukrainy № 2252-1 vid 25.10.2019 r. Verkhovna Rada Ukrainy. Available at: http://w1.c1.rada.gov.ua/pls/zweb2/webproc4_1?pf3511=67183.

7. Yushko S.V. (2013) Navantazhennia na fond oplaty pratsi subiektiv hospodariuvannia yak faktor tinizatsii dokhodiv hromadian. Finansy Ukrainy, no. 2, pp. 32-36. 